\title{
Biblical Evaluative Discourse of Speech and Thought Presentation
}

\author{
Riyadh T. K. Al-Ameedi ${ }^{1} \&$ Sadiq M. K. Al Shamiri ${ }^{1}$ \\ ${ }^{1}$ Dept. of English, College of Education for Human Sciences, University of Babylon, Iraq \\ Correspondence: Sadiq M. K. Al Shamiri, Dept. of English, College of Education for Human Sciences, \\ University of Babylon, Iraq. E-mail: sadiq.hum2016@gmail.com
}

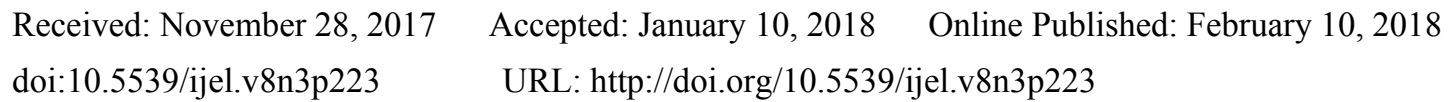

\begin{abstract}
The study aims to highlight the evaluative strategies associated with the Biblical modes of speech and thought presentation. An eclectic pragma-stylistic model of analysis is developed to test the validity of the hypotheses that the targeted modes of discourse are almost always internally and/or externally evaluated by the narrator, and that the reportive modes of speech and thought are evaluative in respect to the quotative modes. The study arrived to the conclusion that different modes of speech and thought are exploited in building narrative genres. These modes form two interrelated types of discourse: quotative and reportive. Four modes contribute to the occurrence of the quotative discourse which are direct speech, free direct speech, direct thought, and free direct thought. The reportive discourse occurs when using one of the reportive modes which include indirect speech, free indirect speech, narrative report of speech act, narrator's representation of voice, indirect thought, free indirect thought, narrative report of thought act, and internal narration. When employed in the targeted Biblical discourse, the quotative and reportive modes are often evaluated by the Biblical narrator. Evaluations of this kind implicate additional meanings and affect reader's interpretation of the represented speeches or thoughts. The Biblical reportive modes are often evaluative in respect to the quotative ones. The Biblical narrator's internal, external, and interactional evaluative strategies contribute to the occurrence of the Biblical evaluative discourse of speech and thought presentation.
\end{abstract}

Keywords: evaluative discourse, biblical discourse, internal evaluation, external evaluation, quotative discourse, reportive discourse

\section{Introduction}

The Gospel part of the New Testament is devoted to narrating the story of Jesus, his birth, teachings, miracles, "crucifixion", "death", and "resurrection". This narrative discourse is mainly built by employing different modes of speech and thought presentation. The employed modes often involve the narrator's addition meanings which take the form of evaluations. The study tries to highlight the evaluative strategies associated with such Biblical modes of speech and thought presentation. An eclectic model of analysis is developed. The developed pragma-stylistic model is intended to test the validity of the hypotheses that the targeted modes of discourse are almost always internally and/or externally evaluated by the narrator, and that the reportive modes of speech and thought are evaluative in respect to the quotative modes.

\section{Literature Review}

The systematic distinction between speech and thought modes of presentation has been introduced, "for the first time" by Leech and Short in 1981 (Semino \& Short, 2004, pp. 9, 14), and it has been republished in the same form in Leech \& Short (2007).

\subsection{The Presentation of Speech}

Leech \& Short (ibid, pp. 255-270) identify five main modes of speech presentation: direct, indirect, free direct, free indirect, and narrative report of speech acts.

\subsubsection{Direct and Indirect Speech}

Direct speech (DS) differs semantically from indirect speech (IS) in the extent of faithfulness: the former is expected to report speech "verbatim", whereas the latter reports the content only. There is a formal relation between these two modes, which is the conversion of DS into IS (ibid, p. 255). This relation illustrates the main formal differences between them: 
(1) (a) He said, I'll come back here to see you again tomorrow.

(b) He said that he would return there to see her the following day. (Leech \& Short, 2007, pp. 255-256)

The IS version of DS above includes several linguistic changes: the relationship between the reporting and reported clauses, tense backshift, altering deictic expressions of the near reference verb, and altering the pronoun to third person. However, the modes of speech changes are not always determined by such formal linguistic indicators only. The reporter's knowledge of some "extra linguistic contextual factors", is also involved.

The reporter of IS "intervenes as interpreter" of the reported speech. In DS, the reporter commits himself to report the form and the content of the speech reported "verbatim" faithfully, whereas in IS, the faithfulness includes the content of speech only. IS should not alter the "truth claim" of the reported speech. As such, there are "more than one possible indirect version of a direct string." Consequently, one "cannot automatically retrieve the original direct speech" from a present IS. Faithfulness assumed in DS may extend the presentation of the original speaker's syntactic and lexical structures to include his pronunciation, as well. This is adopted particularly to express the speaker's attitude, "haughtiness"; that is, to express the communicative value of the sentence. It may include also expressing the original speaker's regional or social class membership (ibid, pp. 257-258).

Toolan (2009, p. 1031) argues that although DS and IS are assumed to be equivalent and alternative forms, they differ particularly in fiction and literary contexts. One can derive many alternative indirect forms of a DS. This is because in fictional narrative, there is "no actual DS counterpart of the IS construction that the writer has composed." In nonfictional contexts, the "“faithfulness" standard may be set much higher, so that IS reporting of speakers may be required or expected to match closely the wording of the real DS source, to limit misrepresentation. In extreme cases or genres (e.g., when giving witness evidence in a criminal trial), IS may be disallowed."

In addition to faithfulness assumption, two more issues are often raised in respect to DS and IS: "formality", and the "dramatic effect". DS is often taken to be more informal (and colourful) than IS which reflects a range of formality of writers and narrators (ibid, p. 1032). Similarly, Lecercle (2006, p. 129) entails that rather than DS, the "fundamental type of speech" is IS. Discussing the dramatic effect of DS, Peters (2004, p. 156) states that "the most dramatic way of reporting what someone said is direct speech, i.e. using not only their words, but their way of projecting them to the listener":

(2) (a) Hammering his shoe on the American table, Kruschev said: "We will bury you." (ibid)

(b) Hammering his shoe on the American table, Kruschev said that the Russians would bury them." (ibid)

\subsubsection{Free Direct Speech}

According to Leech \& Short (2007, p. 258), free direct speech (FDS) is "a more direct form than DS". For Semino \& Short (2004, p. 11), writers make use of FDS by removing one or both of the most indicators of the reporter's presence in DS form: the reporting clause, and quotation marks. By this mode, the character interacts "immediately" with readers without "interference" of narrator, as in (c) below:

(3) (a) He said I'll come back here to see you again tomorrow. (Leech \& Short, 2007, p. 258)

(b) "I'll come back here to see you again tomorrow."(ibid)

(c) I'll come back here to see you again tomorrow. (ibid)

In narrative discourse, FDS may "portray the quick to-and-fro" conversation between characters. Long conversations in novels may be constructed in FDS. It could be used by some writers to deliberately confuse readers about who is being talking, in order to provide interest when readers later on make self-corrections about the right speakers of long FDS constructions. The most free form of FDS is sometimes adopted by some writers using "truncated sentences" of FDS, as Dickens does in the following extract: (ibid)

(4) Now. Is there any other witness? No other witness. Very well, gentlemen! Here's a man unknown, proved to be in the habit of taking opium in large quantities. ... If you think it is a case of accidental death, you will find a verdict accordingly. Verdict accordingly. Accidental death. No doubt. Gentlemen, you are discharged. Good afternoon.

In the above example, Dickens truncates many sentences "to speed up the effect" (ibid, p. 259).

As such, FDS expresses an "extra faithfulness" by providing the original words and grammatical structures. Its main effects are mainly those "vividness and dramatization" (Semino \& Short, 2004, p. 12). (About a new method of characterising the free modes of speech and thought presentation in terms of the Arabic Theory of 
"Iltifat" "discoursal shifts", see Al-Ameedi \& Al-Shamiri (2017)).

2.1.3 Free Indirect Speech

Free indirect speech (FIS) is a mixture of DS and IS. In this mode, most typically, there is an omission of the reporting clause, but the main features of IS, particularly backshift are returned (Leech \& Short, 2007, p. 261):

(5) (a) He would return there to see her again the following day.

(b) He would return there to see her again tomorrow.

(c) He would come back there to see her again tomorrow.

In 5 (a), the construction is FIS because it shares with DS its typical feature of independent clause. Versions 5 (b), and (c), are FIS forms, as well, because they share with DS its typical feature of near deictic expressions, "tomorrow", and "come back" (ibid). As such, Semino \& Short (2004, p. 11) put Leech \& Short's (1981) perspective of FIS in the following way:

In contrast to previous scholars, Leech and Short argued that no particular linguistic features were criterial for FIS to occur. All you needed was a mix of the sorts of features normally associated with DS and IS.

Leech \& Short (2007, pp. 262-264) add that FIS mode "has a rather odd status" in terms of truth claims and faithfulness. It is a half way between interpretation and verbatim presentation of speech. FIS is often associated with "third-person" type of narrator, telling a story in past tense. It is a characteristic of narrative context. Leech $\&$ Short (ibid, pp. 254-255) do not consider the absence of the reporting clause as a criterion of the presence of FIS, because some FIS uses are formed by well-formed ISs with mixture of some features of DS, like lexically colloquial items:

(6) He said he must persuade Billy-Boy to build a pool in the hotel compound one day when old Ma Bhoolaboy was out playing bridge so that when her tonga brought her back at night the whole thingwould tip in with a bloody great splash.

\subsubsection{Narrative Report of Speech Acts}

Leech \& Short (ibid, pp. 258-259) state that "a more indirect form than indirect" is called narrative report of speech acts (NRSA). They are "sentences that merely report that a speech act (or number of speech acts) has occurred". This mode of speech presentation (and its equivalence on thought presentation scale) has been suggested for the first time by Leech and Short in 1981. It "prototypically has only one clause." The speech act presented is often put in the form of a noun phrase or a prepositional phrase after the reporting verb (Semino \& Short, 2004, p. 11):

(7) (a) He promised his return. (Leech \& Short, 2007, p. 259)

(b) He committed himself to another meeting. (ibid)

The main function of such mode is to summarise "relatively unimportant stretches of conversation (ibid, p. 260), and to provide "background speech information to contextualise fuller speech presentation" (Semino \& Short, 2004 , p. 11). Similar to the situation in reporting acts, the writer's attention in reporting speech acts is to encourage readers to see the events "entirely" from the narrator's own perspective, as in "told them the history of his cold", above (ibid). As such, NRSA reveals the speech act value of what is said, and "sometimes" specifies the topic of the speech act (ibid, p. 12).

\subsubsection{Narrator's Representation of Voice}

Toolan (2009, p. 1033) states that "narrator's representation of voice" (NV) is a more indirect mode than NRSA. In NV, the attention is to report that the activity of speaking has occurred. It communicates that an individual spoke without any explicit indication as to what speech acts were performed (Semino \& Short, 2004, p. 44). It is often a "summary reference to speech events that involved a large number of participants" (ibid, p. 45), as in the following example, where $\mathrm{NV}$ is put in boldface type:

(8) (a) We exchanged a few words lazily. (Conrad, Heart of darkness, p. 28), in (Toolan, 2009, p. 1033)

(b) After talks in Belgrade, Mr Milosevic said he fully agreed with the international peace plan. ("Milosevic backs Hurd peace plea", Guardian, 5 December 1994), in (ibid)

Semino \& Short (ibid, p. 14) emphasise that "the definitions of categories for speech presentation above has been done partly on functional grounds (the faithfulness claims), partly on linguistic grounds (made as explicitly as possible) and partly on contextual grounds", in disambiguating some uses of FIS and distinguishing it from narrative proper. 


\subsection{The Presentation of Thought}

Leech \& Short (2007, p. 270) point out that the presentation of thought is concerned with "the portrayal of internal speech". That is to say, "the flow of thought through a character's mind", or what is known as "stream of consciousness." The modes of speech and thought presentation are similar in their formal features. Since minds cannot be measured and seen all modes of thought presentation are "artificial". In presenting their characters' thoughts, writers use the same speech presentation modes, which are "distinguished from one another by similar means":

(9) (a) Does she still love me? (Free Direct Thought)

(b) He wondered, "Does she still love me?" (Direct Thought)

(c) Did she still love him? (Free Indirect Thought)

(d) He wondered if she still loved him. (Indirect Thought)

(e) He wondered about her love for him. (Narrative Report of a Thought Act) (ibid)

Leech \& Short (ibid, p. 271) explain that (a) above resembles free direct thought (FDT). It differs from (b), which is direct though (DT) only in the absence of reporting thought. Sentence (c) is free indirect thought (FIT), since it includes a mixture of DT and indirect thought (IT), that is, the absence of reporting clause, the direct question of the interrogative, and the question mark, are some features of DS, whereas, the backshift of the verb, and the third person pronoun are features of indirect speech. Similar to IS, sentence (d) is an indirect thought (IT) Such form is characteristically distinguished by the presence of a reporting clause, the "explicit" subordination, and the declarative nature of the reported thought. Sentence (e) is a narrative report of thought act (NRTA). It "incorporates what minimal report there is within the main clause by nominalising the reported clause."

Thought presentation modes allow reader to "see things from that character's point of view." Presenting a character's thoughts by any mode of thought is an invitation "to see things from that character's point of view." (ibid, p. 272). The employment of thought presentation modes involves the presence of an "omniscient narrator" (ibid, p. 274). As in speech presentation, DT and FDT give the impression that there is little intervention of the narrator. In extreme forms of FDT, associated with the absence of reporting clause and truncated sentences, a character may show a reader how thoughts of a character may flow rapidly (ibid, p. 275). FIS distances readers somewhat from the characters production of the speech. This is not the case with FIT, which "has the opposite effect." It puts readers "directly inside the character's mind." This difference is reduced to the fact that "the norm or baseline for the presentation of thought is IT, whereas the norm for speech is DS."IT mode is viewed as the norm because of the semantic nature of reporting. In DS, which is the norm of speech presentation, the writer offers the "verbatim" presentation, while in IS, he gives the "substance". DS is possible and common in conversation, Parliamentary and legal reporting, but people's thoughts are not accessible in this way. As such, "a mode which only commits the writer to the content of what was thought is much more acceptable as a norm" (ibid, p. 276).

DT is often used in the form of "the dramatic mode of soliloquy", in an "attempt to make character's thought more actual." FIT is a development of DT. It keeps the vividness of DT and avoids the "artificiality" of soliloquy", that is "speaking to oneself" (ibid).

Similar to speech presentations, writers can use thought presentation modes "strategically" in order to control their readers' "sympathies". This is done by giving extensive account of a character's (who is wanted to be sympathised with) thoughts in the form of FIT. Characters who are not intended to be sympathised with are distanced by never shown their minds (ibid, p. 278).

Toolan (2009, p. 1040) points out that NRTA, and "internal narration" (NI) are suggested by Leech \& Short (1981), and very recently by Semino \& Short (2004), as two counterparts of speech representation NRSA, and NV. NRTA is "roughly parallel to Cohn's [1978] category of psychonarration." "In NRTA, then, there is a highly indirect report of a character's or characters' thought, in which the content is noticeably summarized and cast in narratorial terms":

(10) She had consented to go away, to leave her home. Was that wise? She tried to weigh each side of the question. In her home anyway she had shelter and food; she had those whom she had known all her life about her. Of course she had to work hard, both in the house and at business. (Joyce, "Eveline", Dubliners)

Similarly, internal narration (NI) is a new category proposed by Semino \& Short (2004, p. 132) for "reports of mental states and changes that involve cognitive and affective phenomena but that do not amount to specific thoughts."Toolan (2009, pp. 1040-1041) illustrates reporting such mental activities, which are "less a matter of 
inner speech than NRTA" as:

(11) (a) Jim envied Mr Mulvaney;

(b) The phrase made me a little sad;

(c) I couldn't get the image out of my head.

The above examples need to be imagined in some appropriate contexts. NI is believed to be the most frequent means of thought presentation (ibid).

Leech \& Short (2007, pp. 278-279) maintain that "modes of speech and thought can interact in many different ways, as in the following extract in which "Hemingway dramatises the elemental struggle in the old man's nature in this story of privation, courage and endurance":

(12) "Don't think, old man," he said aloud. Sail on this course and take it "But I must think, he thought. Because it is all I have left ..." (Hemingway,1952, p. 93).

Modes of speech and thought presentation are assumed by the present study to form two types of discourse: quotative and reportive. The former includes direct speech, free direct speech, direct thought, and free direct thought. The latter includes indirect speech, free indirect speech, narrative report of speech act, narrator's representation of voice, indirect thought, free indirect thought, narrative report of thought act, and internal narration.

\subsection{Evaluative Discourse}

This section is intended to investigate the evaluative discourse of modes of speech and thought presentation. Bublitz \& Bednarek (2009, p. 861) state that "evaluation is the central pragmatic function of reported speech." They consider the term "reported speech" as a general term to cover all types of modes of presentation. Labov's (1972) Theory of Narrative Structure has provided insights to linguists, particularly those concerned with pragmatics to develop the idea of "evaluation" in reported speech. The importance and wide acceptability of that theory are assured (Hewings \& North, 2010, pp. 56-57).

Black (2006) discusses the role of reported speech as a main category of the narrative structure, and as a main evaluative strategy that contributes to the overall network of evaluation in that structure. She (ibid, p. 51) considers strategies which involve the reader directly in the text, hence "they are pragmatic, in that they are contextually situated, and invite direct and active reader participation."

Black (ibid, pp. 39-40) remarks that the main concern of Labov's (1972) theory of naturally occurring narratives was those oral narratives told by young Black Americans. However, his theory is also useful for the analysis of written narratives.

An elaborated narrative, according to Labov's theory, consists of: (1) Abstract, (2) Orientation, (3) Complicating action, (4) Evaluation, (5) Result or resolution, and (6) Coda (ibid).

The abstract is typically a summary of the story, the title, in literary works may serve this purpose. The orientation provides the "who", "what", "when", "where" information to introduce the narrative. The "complicating action" is "the core of a narrative". The result "signals the end of the story proper". The coda represents "the tidying-up of the lives of characters, as in the typical fairy-tale probable coda "and they lived happily ever after". Evaluation is "the most interesting and complex category." It can be found anywhere in the text, and Labov thinks it explains why the story is felt to be tellable. Evaluation is often exploited at significant moments in a narrative. She (ibid) assures that "while we might not expect to find precisely the same devices used in written as in oral narratives, Labov's scheme offers a useful framework for analysing such texts."

\subsubsection{Evaluative Categories and Devices}

Labov (1972) divides evaluative devices in narrative context into two categories: "external" and "internal".

\subsubsection{External Evaluative Devices}

Black (2006, p. 40) points out that external evaluative devices are explicitly used by the narrator when he interprets the events to stress their significance. They are likely to express "strong interpersonal function", and often put in "first person" narratives. They are rare in narratives with an "omniscient narrator". The narrator's "generalizations" and "gnomic utterances" belong to this type of evaluation. External evaluations affect the narration by suspending it, however briefly. This is mainly achieved by the use of the present tense involved in these evaluations, which contrast with the normal narrative past tense.

Thornborrow \& Wareing (1998, pp. 119-120) think that in order to insert effective evaluations, writers often 
divide the narrative into two worlds: the narrator's world and the character's one. The type of the narrator plays an important role in enabling the writer to set evaluations towards the characters. An omniscient narrator has the ability to describe even the characters' internal thoughts. The type of the speech reported has also its importance in framing external evaluations. Reporting direct speeches of characters contributes to framing the two worlds mentioned; they mainly frame the characters' world, and make it distinct from that of the narrator, who in such point may set generalisations or comments:

(15) "Congratulations, Mr Rosnovski," he called. "Thank you," said Abel eagerly. "You have a beautiful girl," the doctor said as he reached him. "Thank you," repeated Abel, quietly, trying not to show his disappointment.

In the above example, Abel Rosnovski is presented by the narrator in a hospital, waiting for news of the birth of his child. The underlined speech is an explicit "evaluative discourse". This use is effective since it guides readers to interpret the text through that dominant discourse of the narrator.

They (ibid, pp. 122-123) also discuss the role of "free indirect speech" in evaluation. This mode of speech (and thought) representation is often associated with the omniscient type of narrators. In "realist texts", such role enables the writer to portray the picture of the world of character and his discourse as if it were real. In addition to telling story, the narrator comments and make judgments about the events and the characters. It enables the narrator also in forming the "frame" of two voices: the narrator's and the character's. These two voices are not always clearly separate and identified, hence judgments may be set through the perspective of the character. Free indirect speech also enables writers to present a character's thoughts and at this point the discourse of character and that of the narrator "are blended, or indistinguishable as different voices in the text."

\subsubsection{Internal Evaluative Devices}

Black (2006, p. 41) agrees with Toolan 1998 "that internal evaluative devices are generally more subtle than external evaluation." Among the internal evaluative devices are elements like "negation", "future tense", and "modal verbs", which "temporarily suspend the narrative syntax to move away from the story line and consider unrealised possibilities." In this respect, Cheshire \& Ziebland (2005, p. 22) said "negation functions as internal evaluation in narratives of personal experience." Black (2006, p. 41) adds that these evaluative elements "can occur in dialogue, in passages of indirect speech, or in the narrator's voice", as in the following passage, in which "the protagonist reflects on the time that she wasted bringing up her children":

(16) And for what? They would never live with her again for long. They would go off to public schools, then university, then into careers. She would see them briefly in the holidays when they weren't on school trips. Oh. What a goddamn waste of time, thought this Claudia (Ellis, 1983, p. 137).

Among the evaluative devices in the above example are these self-questioning, and moving between past, present and future. These devices are often associated with depiction of a character's thought, taking the form of reported thought either directly or indirectly, hence they are "more likely to be found in written, rather than oral stories." Other evaluative devices include "metaphor" and "change of narrator". That is, using different voice as narrator. Similar to this is "the move from the narratorial voice to internal focalisation through a character" (Black, 2006, p. 42).

Black's (ibid) final comment on Labov's category of evaluation is that these seemingly heterogeneous devices are all linked by one feature which is that they are all "predominantly interpersonal in their effect"; they directly involve the reader's interpretative effect, and motivate him to perceive rhetorical tropes, like metaphor, and irony. She (ibid) adds that rhetorical devices, intertextuality and considerations of genre can also be considered as evaluative devices.

\subsubsection{Temporal Ordering and Evaluation}

Black (ibid, pp. 43-46) points out that "deviations" from the normal form of narration, which is "a temporally ordered sequence, will almost certainly contribute significantly to the network of evaluation devices." Stories are hardly narrated in strictly chronological order "A-B-C". Reordering is quite normal and required in such genre. This is apparent in some types of stories like the detective, in which the order is often reversed; "C-B-A", for instance, beginning with a discovery of a corpse, followed by some events that lead to the murder. Three aspects of the temporal organisation of narrative: "Order", "Duration", and "Frequency", contribute to the evaluative aspect of a text since they affect the reader's "reception" of the text.

\subsection{Order}

This aspect "answers the questions: What happened first, next, last?" It is probably the most obvious category of the temporal ordering. Departure from chronological order is often intended, in addition to maintain interest, for 
instance in detective stories, but also as an evaluative device (ibid).

\subsection{Duration}

Duration as one of the aspects of temporal organization answers the question "How long?". It "is the most difficult and elusive of these categories, because it attempts to relate the time taken for the putative events to occur in the "real world", that is in "story time", to the time taken to narrate them". It is common in most stories that time passes and events occur without words devoted in the text. This is called ellipsis, which is mainly intended to provide interest in Leech's (1983, pp. 146-147) terms, since the less interesting events of the characters' lives are normally skipped. Novelists often skip years, since a novel is not history. On the contrary, "stretch" is the other extreme, when "events take longer to narrate than their occurrence would", as in the description of the moments before death which may take days in narration (Black, 2006, pp. 44-45).

\subsection{Frequency}

Frequency answers the question "How often?"This category "is less problematic, and perhaps interpretively less interesting." (ibid).

Black (ibid:47-8) argues that "all the evaluative devices" can be explained according to Grice's co-operative principle, since they generate implicatures in the overall act of the text. Many of these devices involve the maxim of manner. She (ibid, p. 48) emphasises that "the temporal organisation of narrative is very likely to function as a major evaluative device", and has a close relation with Labov's account of evaluation.

\subsubsection{Intertextuality}

Black (ibid, p. 49) defines intertextuality as "part of the network of evaluative devices found in literary discourse." It acts in complex ways to deepen the meaning of the text. Intertextuality is defined in different ways, and the narrowest is that "it denotes the echo or invocation of another text."Norman (2003, p. 39) clarifies that intertextuality takes two main senses; one is obvious, which is the presence of actual elements of other texts within a text, in the form of "quotations". The second is less obvious, when it takes different forms of represented speech and thought. Lazer $(2007$, p. 181) believes that considering language as a form of social practice, i.e., discourse, has been influenced by Bakhtin's (1986) perspective of "voice", "intertextuality" and "interdiscursivity". The term "voice" refers to "the language which identifies a particular group, while intertextuality can be defined as the voice of another in a text (for example, in reported speech)." Fairclough (2003a), as cited in Blackledge (2005, pp. 10-11), "suggests that an important aspect of intertextuality is the representation or reporting of speech, writing or thought within a text." Norman (2003, p. 219) also concludes that intertextuality may include different tools; yet "the most common and pervasive form" is reported speech, writing, and thought.

\subsection{Intertextuality of Direct Speech}

Analysing complaint stories regarding the role of "intertextuality" in generating evaluations, Cunthner (1997:188-9) emphasises that "although direct speech may claim authenticity, it can never be a verbatim, mimetic reproduction of the original utterance." This is because using "direct speech" in another text involves "decontextualizing" it from its original context and "recontextualizing" it in a new interactive scene. Reconstructed dialogue always undergoes the process of transformation, hence it can never be "identical" to its original. Intertextuality of "direct speech", as a result, includes a selection of certain elements, stylizing certain features, and focusing certain aspects. As such, she agrees with Tannen's (1986, p. 312) viewpoint that "constructed dialogue" is a rhetorical means "by which experience surpasses story to become drama." Cunthner (1997, pp. 188-189) adds that by presentation of speech, the narrator creates what is called "staging" of the story, which is an important device to produce lively interaction and reduce "the distance between story world and participant world and creates a common context to evaluate the present events." Thus, she (ibid) agrees also with Bakhtin (1986) that intertextuality creates relationships between the present event of the story, and the previous, and therefore, it plays a serious role in permitting its users "to create multiple modes of inserting their own evaluations into the discourse, and to build up different perspectives on what is taking place."

A fruitful exploitation of this type of intertextuality is in the field of "language and globalization". Hodges (2010, p. 306) thinks that in the study of "language and globalization", linguists "need to pay attention to the way discourse travels around the world and is taken up and reshaped by actors in local situations." He (ibid) adds that the notion "dialogism", known also as "intertextuality", is useful in the analysis of "global discursive interchange", since it "emphasizes the connections across multiple discursive encounters where issues are contested." Intertextuality is adopted when a discourse is "decontextualized" from one setting and "recontextualized" into another discursive encounter (Bauman \& Briggs, 1990; Briggs \& Bauman, 1992), in 
(ibid).

\subsection{Intertextuality of Indirect Speech}

Cunthner (1997, p. 190) argues that "layering of voice", and ultimately expressing the narrator's evaluation, is also achieved with the aid of indirect reported speech. This type of intertextuality is also called "manifest intertextuality" (Fairclough, 1992), in Sunderland \& Litosseliti (2002, p. 14). It differs from "intertextuality" achieved by means of mixing together different discourses and genres. Thus, Cunthner (1997, p. 190) agrees with Silverstein (1993) who views reported speech as a "metapragmatic activity"; "by quoting past utterances, speakers explicitly represent and comment on the use of language." Moreover, and as Messick (2003, p. 180) maintains, every "indirect speech" involves "intertextual movement" via the relations between reported and reporting texts in the sense that "the reported text both retains certain connecting filament, and resonances with its original textual site and also assumes new attachments and significances in the reporting text."

More precisely, Norman (2003, pp. 49, 51) observes four ways of reporting, all of which are forms of intertextuality: "direct", "indirect", "free indirect", and "narrative report of speech act". In using them, intertextuality is "a matter of recontextualization"; that is, "a movement from one context to another." This movement entails particular transformations which result from the way in which that media is moved, and recontextualized within the new context. In the case of reported speech, writing or thought, there are two interconnected issues to address: (a) the relationship between the reported material and the original (the event that is reported); (b) the relationship between the reported material and the rest of the text in which it occurs; how the report figures in the text, and its function in the new text.

He (ibid, pp. 53-54) adds that when the voice of another is mixed within a text, the question is "how to frame it"; that is, how to contextualize it. Framing is usually done by a reporting verb:

(17) The UN Secretary General is reported to have been taking a tough line with Libya, demanding that it specify when the two suspects would be handed over.

Norman (ibid) explains that in this report, which is taken from BBC, UN correspondent, about the Lockerbie Case, the framing is partially achieved by the reporting verb chosen. It is "highly improbable that the Secretary General said "I demanded that ..." The choice of the verb "demand" rather than other verbs, like, for example, "ask" "would seem to be a framing conducive to an interpretation which cast the Libyans in an unfavourable light: if the supposedly impartial UN is getting tough with Libya, they must be in the wrong." Several voices manifest in this report: "the West, the UN, the Libyans, and the BBC correspondent." He (ibid, p. 54) states that there are two important issues about voices in narration: (1) "different voices draw upon different discourses." (2) the representation of voices may be explicitly or implicitly ranging from direct into indirect new form of what was said or written.

Findings of intertextuality can be generalised to other modes of speech and thought presentation. Li (2009:109) concludes that free indirect speech provides "a high degree of identification between the reported voice and the authorial voice."

\subsubsection{Foregrounding}

Foregrounding of a textual element can also be regarded as an evaluative device according to the Labovian framework, e.g., "post-nominal modification", "pre-nominal repetition" of a previous post-nominal, and the like (Black, 2006, p. 51). Foregrounding, however, is relevant to the present account of evaluation mainly when it is associated with some types of reported speech or thought (for more details, see Kadhum (1996)).

\subsubsection{Register, Genre, and Evaluation}

Machen-Hararik \& Adaniou (2008, pp. 369-370) state that to analyse a complex genre like "telling a story", "providing instruction for a task", or "arguing a case", one can appeal to the notion of register (field, tenor, and mode), in addition to generic structure, which "is used to describe the sequence of the communicative acts in a text e.g., explaining, describing, evaluating", and so on. Evaluating is a crucial stage in a narrative partially because it answers "the "so what" question that threatens the validity of the tale and its teller."

In narratives, they (ibid, pp. 373, 376-377) add that "field" is the "topic" of the story, and that every narrative creates a possible world of problematic experience for one or more characters. "Toner" involves the animation of the relationships of character's and the reader's evaluation of the significance of what happens, that is positioning the reader to respond with feelings like "empathy", "suspense", "judgement", and "humour". Tenor enables readers to work with "point of view", often called "focalization". Tenor in narratives offers a view of text-audience relations, that is, how experience is evaluated by narrator, character, and more covertly, by the text 
as a whole; and this extends the discussion within narrative theory into the territory of "point of view". Tenor, as such, "creates drama in narrative." The main aim of "mode" is to "compose a text that coheres with itself and with its context." Unlike other texts, in written narratives, the reader relies on language alone to build the context for interpretation.

\section{Methods}

The study adopts an eclectic pragma-stylistic model to analyse the targeted discourses. As its label indicates, the model involves two interrelated levels of linguistic investigation: stylistic and pragmatic.

\subsection{The Stylistic Level of Analysis}

The stylistic level of analysis aims to identify the quotative modes of speech and thought presentation which contribute to the occurrence of a quotative discourse within a narrative religious discourse. These quotative modes, according to the theoretical account of the study include "direct speech", "free direct speech", "direct thought", and "free direct thought". When identified, each mode undergoes a stylistic analysis which mainly concentrates on its stylistic features ( $\mathrm{SFs}$ ) which distinguish it from other modes. Following the stylistic methodology, these features include some syntactic aspects, like the structure of the mode.

However, the stylistic analysis also covers that closely related type of discourse, which is the reportive one, and its internal modes. The reportive discourse involves "indirect speech", "free indirect speech", "narrative report of speech act", "narrator's representation of voice", "indirect thought", "free indirect thought", "narrative report of thought act", and "internal narration". These modes of the reportive discourse add meanings to the quotative ones when they occur within the same narrative discourse. The quotative discourse and the relevant types of discourse like the reportive, and the pure narrative are identified according to the findings of the study in its theoretical part, particularly according to Leech \& Short's (1981, 2007), and Semino \& Short's (2004) stylistic models of speech and thought presentation.

\subsection{The Pragmatic Level of Analysis}

Narrators of the quotative discourse are often intentionally involved by adding explicit and/or implicit meanings to the stylistic modes. Their involvements produce implicatures. They are called by the present study evaluations. The narrators, whether main or internal, adopt different internal and/or external evaluative strategies to add such meanings, like labelling the subject, modifying the quotative verbs by other verbs, adverbials, and so on. They also add meanings to the used modes by some explicit comments on the speech or thought quoted. These evaluations on the part of the narrators are often supported by evaluating the quotative discourse by its relative one, which is called the reportive discourse. Thus, the analysis concentrates mainly on the internal, external, and interactional types of the evaluative strategies (ESs). These are more technically labelled and analysed according to Black's (2006) account of evaluation. The study has adopted a rather new procedure in order to test the workability of the model (as in 3.3 below).

\subsection{The Procedure of Applying the Model}

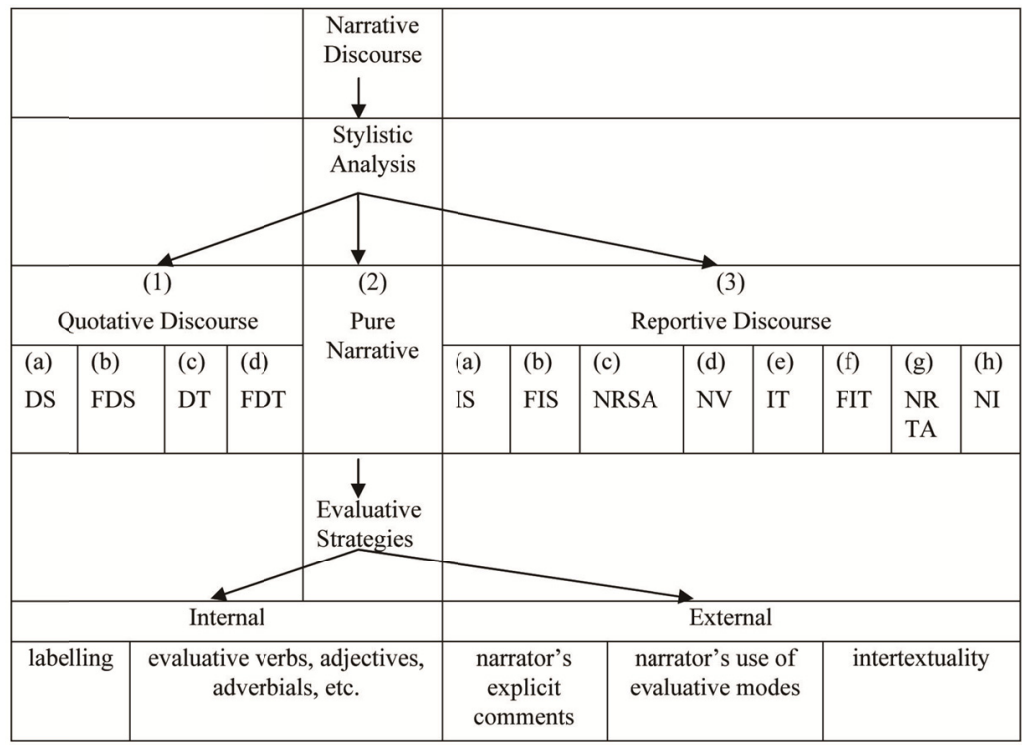

Figure 1.Evaluative strategies of speech and thought presentation 
Rather than analysing some isolated texts removed from their contexts, the model is applied to some larger extracts (Exs) in order to present the quotative discourse, and the interrelated discourses in their real contexts to highlight, among other ends, that interaction among the targeted modes of speech and thought presentation. This procedure is hoped to agree with the discoursal nature of the study. When identified, the quotative discourse (QD) within each extract is highlighted by normal underlining, while the reportive discourse (RD) is highlighted by dotted underlining. What is not underlined is a discourse of pure narrative $(\mathrm{PN})$. The figure above summarises the model of the study.

\section{Data Analysis}

In this section, two representative Biblical extracts are analysed. They are assumed to involve the targeted types of evaluative discourse.

Extract (1):

"1:18 Now the birth of Jesus Christ was on this wise: When as his mother Mary was espoused to Joseph, before they came together, she was found with child of the Holy Ghost. 1:19 Then Joseph her husband, being a just man, and not willing to make her a publick example, was minded to put her away privily. 1:20 But while he thought on these things, behold, the angel of the LORD appeared unto him in a dream, saying, Joseph, thou son of David, fear not to take unto thee Mary thy wife: for that which is conceived in her is of the Holy Ghost. 1:21 And she shall bring forth a son, and thou shalt call his name JESUS: for he shall save his people from their sins. 1:22 Now all this was done, that it might be fulfilled which was spoken of the Lord by the prophet, saying, 1:23 Behold, a virgin shall be with child, and shall bring forth a son, and they shall call his name Emmanuel, which being interpreted is, God with us. 1:24 Then Joseph being raised from sleep did as the angel of the Lord had bidden him, and took unto him his wife: 1:25 And knew her not till she had brought forth her firstborn son: and he called his name JESUS" (Matt. 1[18-25]).

Ex (1) involves different types of quotative and reportive modes of discourse (MDs) and evaluative strategies (ESs):

(a) Indirect Thought (IT) (1):

(i) Stylistic Features (SFs):

Text 1:18 of Ex (1) provides the context of Jesus' birth. As for text 1:19, it belongs to the reportive discourse (RD) that includes three indirect modes. The first mode used in this text (and in the New Testament as a whole) is reportive. It is an IT represented by "Then Joseph her husband, being a just man, and not willing to make her a publick example". It is a negative indirect thought. The negated reportive verb (RV) "will", which describes inner state, is followed by a "to-complement clause", which indicates the indirect nature of the mode. The use of this mode reveals the omniscient nature of the Biblical narrator.

\section{(ii) Evaluative Strategies (ESs):}

The subject of the reporting clause of Mode (a) is internally evaluated by labeling "her husband". The "her husband" piece of information is not redundant; it implicates that although he is her husband; he is able to tolerate the situation, out of being kind. After labelling the subject of Mode (a), the narrator explicitly evaluates it by two additional comment clauses: "being a just man, and not willing to make her a publick example". These comment clauses form external evaluations of the reported thought; they are clearly the narrator's. The reported clause of Mode (a), on the other hand, is further evaluated by that adverbial clause "But while he thought on these things" of 1:20, which means that Joseph has not revealed his inner thoughts, which is an internal evaluation. Thus, Mode (a) is evaluated by Mode (c).

(b) Indirect Thought (2):

(i) SFs:

The second mode in Ex (1) is also reportive. It is an indirect thought (IT), represented by "Joseph her husband, being a just man, and not willing to make her a publick example, was minded to put her away privily." It is a thought presentation mode since the RV used "mind" expresses inner speech. This is also expressed explicitly by the verb "thought" in 1:20. The verb "mind" is also followed by a "to-complement clause", which indicates the indirect nature of the mode. The omniscient narrator is able to express inner thoughts, hence the faithfulness principle to the exact reported thought is preserved; the thought represented in such a way which is assumed to be the closest interpretation of Joseph's inner speech. Syntactically, the indirect thought in 1:19 includes a reporting clause of thought, which has two "obligatory" parts: the subject "Joseph", and the RV "was minded". The reported clause is "to put her away privily". 
(c) Narrative Report of Thought Act (NRTA):

(i) SFs:

This mode is represented by "But while he thought on these things". This construction includes a RV of inner speech "thought", followed by a prepositional phrase "on these things". Mode (c) forms an adverbial clause of time within a complex sentence that produces another discourse.

(ii) ESs:

The use of Mode (c) implicates that Joseph's thoughts revolve on such a decision, "to put her away privily"; none of his thoughts does not match with his "kindness" and "justice". This NRTA modifies (evaluates) the mode to follow which is a direct speech (DS) of the angel of the Lord, as he explicates the identity of Jesus and his birth because it functions as an adverbial clause of time in relation to the following quotative mode (QM).

(d) Direct Speech (DS) (1):

(i) SFs:

This is the first QM in Ex (1) and in the New Testament as a whole. It extends over Texts 1:20, and1:21. It is approximately a long DS of the angel of the Lord which includes two coordinated reported clauses. The narrator employs this mode since its content is crucial. This DS includes a reporting clause, "the angel of the LORD appeared unto him in a dream, saying", and the reported clause, which extends from "Joseph, thou son of David", of text 1:20, until "for he shall save his people from their sins." of 1:21. The reporting clause includes its obligatory elements: the subject "the angel of the Lord"; and the nominal form of the QV "say". The addressee as an optional element within the reporting clause is also explicitly expressed (the pronoun "him", i.e., Joseph'). The pronouns "thou", and "thy" indicate the direct nature of the mode.

(ii) ESs:

The reported clause of DS (1) is internally evaluated by labelling the speaker by that noun phrase (the angel of the Lord) preceded by a direct address word of hearer/reader (the interjection "behold"), which stimulates the hearer's/reader's involvement and seeks his attention.

(e) Direct Speech (2):

(i) SFs:

Ex (1) includes a second direct speech, which is that quoted speech by the narrator of the Lord delivered long before by unspecified prophet: "Behold, a virgin shall be with child, and shall bring forth a son, and they shall call his name Emmanuel". The Lord's direct speech is preserved in its original form verbatim, which is in future time form, ended with a comment clause of the narrator "which being interpreted is, God with us".

(ii) ESs:

The main evaluative strategy of the reported clause of DS (1) is external. It is that "intertextuality", represented by DS (2) of that prophet's long before prediction (Behold, a virgin shall ...). That prophet's DS has been decontextualised by the narrator and recontextualised within this long quotative mode. Such use of intertextuality is intended to support the argument concerning Jesus' birth, and his identity. In addition, DS (2) is evaluated externally by that comment clause of the narrator "which being interpreted is, God with us".

(f) Narrative Report of Speech Act (NRSA):

(i) SFs:

Text 1:24 is contextual of pure narrative (PN). Text 1:25 provides another RM of speech presentation, "and he called his name JESUS", which informs the way Joseph submits to the Lord's message. This mode is more indirect than indirect speech, and useful in summarising the events. The speech act reported is "naming", and is put in the form of a finite clause.

(ii) ESs:

This mode does not include an explicit internal or external evaluative strategy on the part of the narrator. However, this RM of speech presentation is intended to end the episode by means of "acceleration".

Extract (2):

"3:1 In those days came John the Baptist, preaching in the wilderness of Judaea, 3:2 And saying, Repent ye: for the kingdom of heaven is at hand. 3:3 For this is he that was spoken of by the prophet Esaias, saying, The voice of one crying in the wilderness, Prepare ye the way of the Lord, make his paths straight. 3:4 And the same John 
had his raiment of camel's hair, and a leathern girdle about his loins; and his meat was locusts and wild honey. 3:5 Then went out to him Jerusalem, and all Judaea, and all the region round about Jordan, 3:6 And were baptized of him in Jordan, confessing their sins. 3:7 But when he saw many of the Pharisees and Sadducees come to his baptism, he said unto them, $\mathrm{O}$ generation of vipers, who hath warned you to flee from the wrath to come? 3:8 Bring forth therefore fruits meet for repentance: 3:9 And think not to say within yourselves, We have Abraham to our father: for I say unto you, that God is able of these stones to raise up children unto Abraham. 3:10 And now also the axe is laid unto the root of the trees: therefore every tree which bringeth not forth good fruit is hewn down, and cast into the fire. 3:11 I indeed baptize you with water unto repentance. but he that cometh after me is mightier than I, whose shoes I am not worthy to bear: he shall baptize you with the Holy Ghost, and with fire: 3:12 Whose fan is in his hand, and he will throughly purge his floor, and gather his wheat into the garner; but he will burn up the chaff with unquenchable fire. 3:13 Then cometh Jesus from Galilee to Jordan unto John, to be baptized of him.3:14 But John forbad him, saying, I have need to be baptized of thee, and comest thou to me? 3:15 And Jesus answering said unto him, Suffer it to be so now: for thus it becometh us to fulfil all righteousness. Then he suffered him. 3:16 And Jesus, when he was baptized, went up straightway out of the water: and, lo, the heavens were opened unto him, and he saw the Spirit of God descending like a dove, and lighting upon him: 3:17 And lo a voice from heaven, saying, This is my beloved Son, in whom I am well pleased" (Matt.3[1-17]).

Ex (2) is about John the Baptist. It is a linking narrative discourse within the New Testament. One of its functions is to accelerate the events; it summarises several years of Jesus' early youth, and paves the way to a more relevant discourse of the declaration of Jesus' public appearance. This period is filled by introducing John the Baptist announcing the good news of the long been waited rescuer, Jesus. For their significance, John's speeches are put in the form of several quotative speeches in which the narrator's voice is apparent. Thus, the dominant discourse of this extract is quotative. However, two instances of RD are also employed.

(a) Narrator's Representation of Voice (NV):

(i) SFs:

Ex (2) opens the scene by reporting John's voice by means of a NV. It is a RM which is more indirect than the IS, and NRSA, as it reports the happening of the speech event of "preaching". It summarizes long speeches: "came John the Baptist, preaching".

(ii) ESs:

Mode (a) is employed to modify the QV "say" of the DS to follow, i.e., Mode (b), which is an internal evaluative strategy on the part of the Biblical narrator.

(b) Direct Speech (1):

(i) SFs:

This is a direct speech of John the Baptist. Part of the reporting clause of which is within the preceding RM of NV(texts 3:1-3).

(ii) ESs:

In DS (1), "Repent ye: for the kingdom of heaven is at hand". John's direct speech is internally evaluated; the $\mathrm{NV}$, which is embedded as an adverbial clause within the reporting clause, evaluates the QV "say" to give it the sense of "preach". It implicates that he has followers, and audience. The QV "say" is put in its nominal gerundial form to express the frequent happening of the speech.

(c, d) Direct Speech (2, 3):

(i) SFs:

In this mode, the Biblical narrator quotes Prophet Esaias speech: "For this is he that was spoken of by the prophet Esaias, saying, The voice of one crying in the wilderness, Prepare ye the way of the Lord, make his paths straight." Interestingly, the quoted speech of Prophet Esaias, which is a prophecy, quotes John's speech while preaching in the future, hence an embedded DS is also involved.

(ii) ESs:

DS (2), which is delivered by Prophet Esaias, is quoted here and functions as an external evaluation to evaluate the quoted direct speech of John by means of intertextuality. Mode (c) itself is internally evaluated by labelling the subject "the prophet Esaias". Mode (d), which is the embedded DS (3), is internally evaluated by labelling the subject of the reporting clause, and by using the evaluative quotative verb (QV) "cry". 
(e) Narrative Report of Speech Act (1):

(i) SFs:

Texts 3:4-5 of Ex (2) describe John the Baptist, what he wears and eats, and his baptism. Mode (e) reports that people go to John in order to baptise and confess their sins. Their speeches while confessing are less important than the act itself, hence their act is summarised by a NRSA, "speech act of confessing sins". The above three texts summarize John's role, hence the narrator employs NRSA that does the task of summarising. However, it seems that not only good people go to John; some hypocrites go there, too.

(ii) ESs:

Mode (e) has not been evaluated by the Biblical narrator.

(f) Indirect Thought (1):

(i) SFs:

This is a mode of thought presentation. The RV of the indirect thought "see" is used in the sense of "realize": $3: 7$ But when he saw many of the Pharisees and Sadducees come to his baptism". The subordination of the reported clause indicates the indirect nature of the mode.

(ii) ESs:

Mode (f) internally evaluates the following QD since it is an adverbial clause of time, the main clause of which forms the evaluated discourse.

(g, h) Direct Speech (4); Indirect Thought (2):

(i) SFs:

In Texts 3:7-10, John, having the ability to know others' inner thoughts, addresses some unfaithful Pharisees and Sadducees, who also hypocritically join people to baptise. John's speech is reported directly; it is approximately a long DS, hence the reporting clause is used one time only in text 3:7. The mode is quotative since the first reported clause is put in the form of a direct question in which John rebukes the addressees. The quoted speech includes several coordinated clauses. The whole direct speech is a complex-compound sentence, which extends from text 3:7 to text 3:10. The reported clause in 3:8 is linked to the preceding one in 3:7 by the coordinator "therefore". The reported clause of text 3:9 is linked to what precedes by the coordinator "and". Similarly the reported clause of text 3:10 is also coordinated with that of text 3:19 by "and".

In Text 3:9, John acts as an inner narrator. Having an omniscient ability, John reports the inner thoughts of the same addressees in Mode (g) above, "And think not to say within yourselves, We have Abraham to our father". John uses the RV of thought "say within yourselves". Although the pronouns used in the reported clause are of the first person which are in principle suitable to DS forms; yet the plural subject indicates their indirect nature. Whatever those people exactly said to themselves, their thoughts revolve on the idea reported "We have Abraham to our father". The indirect thought of those people reported by John itself is reported by the main biblical narrator, as he continues quoting John's speech, which starts in text 3:7.

(ii) ESs:

DS (4) is internally evaluated by Mode (f), which functions as an adverbial clause of time to this mode. The direct speech of Mode $(\mathrm{g})$ is internally evaluated by labelling the addressees within the reported clause, in Mode (f), "Pharisees and Sadducees".

(i) Free Direct Speech (FDS):

(i) SFs:

Texts 3:11-12 form a new QM of speech presentation, which is a free direct speech. It is a FDS of John since it offers a direct speech of him without a reporting clause, and without been subordinated or coordinated to the preceding reported clauses of the preceding DS. It employs first and second person pronouns. It is put in the form of some linked reported clauses. It seems that in presenting a long direct speech of John, the narrator unconsciously employs what is called in Arabic aliltifat, which is that discoursal shift from one type of discourse into another. This technique is required in producing free types of speech and thought presentation. In this extract, the last coordinated "reported clause" of the DS referred to in Mode (h) can be seen as a kind of "absentee discourse": "therefore every tree which bringeth not forth good fruit is hewn down, and cast into the fire". Although it is part of John's speech, he in that very clause sets general statement using third person pronouns. Then in text 3:11, John shifts into a "speaking discourse": "I indeed baptize you with water unto repentance. 
buthe that cometh after me is mightier than I", producing a FDS.

(ii) ESs:

This part of Ex (2) can be viewed as an external ES by means of intertextuality. The narrator decontextualises John the Baptist's speeches from their original contexts and recontextualises them before the declaration of Jesus' first speeches within the New Testament. John's QD above is meant to credentialise the whole upcoming Jesus' speeches and show his status among the prophets.

(j, k) Narrative Report of Speech Act (2), Direct Speech (5):

(i) SFs:

Having prefaced the whole story of the New Testament, the narrator shifts and pushes the events into the main detailed purposes of the Bible as it is delivered now by Jesus himself for the first time in the following part of Extract 2. The intended reader has been involved by means of many strategies, among the most important ones is that linguistic manipulation of speech and thought presentation. The direct function of the rest of Ex (2) is presenting the shift of baptism from John into Jesus. Texts 3:13, and 16 are contextual, and texts 3:14, and 15 are quotative representing direct speeches of John and Jesus; and 3:17 is evaluative QD.

The form "But John forbad him," is a NRSA of "forbidding". The direct nature of the mode is indicated by the use of the present tense and first and second person pronouns. For its relative importance, the exchange between John and Jesus is reported verbatim. This mode represents the first pair of the exchange which takes the form of a direct question and its answer.

(ii) ESs:

The contextual text 3:13 is intended to link the events. The last time Jesus is mentioned when he is a child in Nazareth under the care of Joseph. Jesus knows well his religious status in respect to John's. However, he is so humble and polite that he asks John to baptise him. Although this is not explicitly expressed by external evaluation; yet this is understood from text 3:14 which reports an exchange between them. Text 3:14 is a direct speech of John. It is initiated by "but" that expresses a concessive meaning. The reported clause of DS (5) is internally evaluated by the clause "but John forbad him", which is an evaluative NRSA. The RM (j) is an external evaluation of the quotative mode that follows, which is DS (5) of Mode (k).

(1) Direct Speech (6):

(i) SFs:

This is the second part of the talk exchange between John the Baptist and Jesus. It is reported in the form of a direct speech, which is apparent from its structure: "3:14 But John forbad him, saying, I have need to be baptized of thee, and comest thou to me?". The speech quoted supports that both participants know his own and his interlocutor's statuses; Jesus knows his status, and knows that John does, hence he uses the imperative "suffer". Although syntactically the reported clause of the direct speech in this text is imperative, it is understood by readers to be a request.

(ii) ESs:

DS (6) is internally evaluated by modifying the RV "say" with "forbad".

(m) Narrative Report of Speech Act (3):

(i) SFs:

The final sentence in text 3:15 reports John's answer to Jesus' reported direct request. It is put in the form of a NRSA, which is "acceptance": "then he suffered him". After narrating this speech act, the narrator records the events immediately following the baptism of Jesus in order to pave the way to one of the most crucial beliefs in Christianity.

(ii) ESs:

Mode ( $\mathrm{m}$ ) does not include evaluation on the part of the narrator.

(n) Direct Speech (7):

(i) SFs:

In this QM, the narrator quotes a speech of "the Spirit of God": "3:17 And lo a voice from heaven, saying, This is my beloved Son, in whom I am well pleased." Unlike most direct speeches of the Bible, the reporting clause of this DS includes only the obligatory parts: the subject, and the nominal form of the QV "say". The addressee has 
not been specified. It may be intended to be "all people of all generations". This is because the direct original hearers of that speech are John and Jesus, who already knew the content of the reported clause, "This is my beloved Son".

(ii) ESs:

The mode is internally evaluated by labelling the subject of the DS as "a voice from heaven".

(o) Internal Narration:

(i) SFs:

This is a RM of thought presentation. It is a narration of an inner state. The voice from heaven reports His inner state of pleasure. The reportive adjective "pleased" is used.

(ii) ESs:

Using simile and quoting the spirit of God's speech, the narrator's external evaluative strategy in Modes (n) and (o) is intertextuality. It is to evaluate the already quoted speeches of John and Jesus. It is intended to establish this main Christian belief, which will be further emphasised and evaluated again and again throughout the New Testament. It is intended to serve as an all times emphasised saying, which ultimately supports the claimed objectivity of the narrator. From now on Jesus is given the floor, and John's identity has been melt within that of Jesus, hence John will be seldom reported.

\section{Conclusion}

It has been concluded that different modes of speech and thought are exploited in building narrative genres. These modes form two interrelated types of discourse: quotative and reportive. Four modes contribute to the occurrence of the quotative discourse which are direct speech, free direct speech, direct thought, and free direct thought. The reportive discourse occurs when using one of the reportive modes which include indirect speech, free indirect speech, narrative report of speech act, narrator's representation of voice, indirect thought, free indirect thought, narrative report of thought act, and internal narration. When employed in the targeted Biblical discourse, the quotative and reportive modes are often evaluated by the Biblical narrator. Evaluation of this kind contributes to the establishment of religious beliefs as they affect reader's interpretation of the represented speeches or thoughts. The Biblical reportive modes are often evaluative in respect to the quotative ones. The Biblical narrator's internal, external, and interactional evaluative strategies contribute to the occurrence of the Biblical evaluative discourse of speech and thought presentation.

\section{References}

Al-Ameedi, R. T., \& Al-Shamiri, S. M. (2017). Biblical and Qur'anic Discoursal Shifts: Generating Free Modes of Speech and Thought Presentation Via "Iltifat". International Journal of Advanced Research, 5(11), 712-227. http://dx.doi.org/10.21474/IJAR01/5825

Bakhtin, M. (1986). Speech Genres and other Late Essays. Austin: University of Texas Press.

Bible, King James Version. (1997). Retrieved from http://www.quod.lib.umich.edu

Black, E. (2006). Pragmatic Stylistics. Edinburgh: Edinburgh University Press.

Blackledge, A. (2005). Discourse and Power in a Multilingual World. Amsterdam: John Benjamins Publishing Company. https://doi.org/10.1075/dapsac.15

Bublitz, W., \& Bednarek, M. (2009). Reported Speech: Pragmatic Aspects. In J. L. Mey (Ed.), Concise Encyclopedia of Pragmatics (2nd ed., pp. 861-864) Amsterdam: Elsevier Ltd.

Cheshire, J., \& Ziebland, S. (2005). Narrative as a Resourse in Accounts of the Experience of Illness. In J. Thornborrow \& J. Coates (Eds.), The Sociolinguistic of Narrative (pp. 17-40). Amsterdam: John Benjamines Publishing Company. https://doi.org/10.1075/sin.6.02che

Cunthner, S. (1997). Complaint Stories: Constructing Emotional Reciprocity among Women. In H. Kotthoff \& R. Wodak (Eds.), Communicating Gender in Context (pp. 179-218). Amsterdam: John Benjamins Company. https://doi.org/10.1075/pbns.42.10gun

Ellis, A. T. (1983). The Other Side of the Fire. Harmondsworth: Penguin.

Fairclough, N. (1992). Discourse and Social Change. Cambridge: Polity Press.

Fairclough, N. (2003). Analysing Discourse. Textual Analysis for Social Research. London: Routledge.

Hewings, A., \& North, S. (2010). Texts and Practices. In J. Maybin \& J. Swann (Eds.), The Routledge 
Companion to English Language Studies (pp. 42-75). London: Routledge Taylor and Francis Group.

Hodges, A. (2010). Discursive Constructions of Global War and Terror. In N. Coupland (Ed.), The Handbook of Language and Globalization (pp. 305-322). Oxford: Blackwell. https://doi.org/10.1002/9781444324068.ch13

Kadhum, R. T. (1996). Foregrounding in English and Arabic with Reference to Translation. Unpublished Ph. D. Dissertation: Al-Mustansiriya University.

Labov, W. (1972). Language in the Inner City: Studies in the Black English Vernacular. Philadelphia: University of Pennsylvania Press.

Lazer, M. M. (2007). Feminist Critical Discourse Analysis: Gender, Power and Ideology in Discourse. London: London: Palgrave.

Lecercle, J. (2006). A Marxist Philosophy of Language. Leiden: Brill.

Leech, G. (1983). Principles of Pragmatics. Harlow: Longman.

Leech, G. (2007). Style in Fiction: A Linguistic Introduction to English Fictional Prose (2nd ed.). London: Longman.

Leech, G., \& Short, M. (1981). Style in Fiction: A Linguistic Introduction to English Fictional Prose (1st ed.) London: Longman.

Li, J. (2009). Intertextuality and National Identity: Discourse of National Conflicts in Daily Newspapers in the United States and China. Discourse and Society, 20(1), 85-121. Los Angeles: Sage Publications. https://doi.org/10.1177/0957926508097096

Machen-Hararik, M., \&Adaniou, M. (2008). Genre and Register in Multiliteracies. In B. Spolsky \& F. M. Hult (Eds.), The Handbook of Educational Linguistics (pp. 367-382). Oxford: Blackwell Publishing Ltd. https://doi.org/10.1002/9780470694138.ch26

Messick, B. (2003). Notes on Transliteration. In P. G. Rubel \& A. Rosman (Eds.), Translating Cultures: Perspectives on Translation and Anthropology (pp. 177-196). Oxford: BERG.

Norman, F. (2003). Analysing Discourse: Textual Analysis for Social Research. London: Routledge.

Peters, P. (2004). The Cambridge Guide to English Usage. Cambridge: Cambridge University Press. https://doi.org/10.1017/CBO9780511487040

Semino, E., \& Short, M. (2004).Corpus Stylistics: Speech, Writing and Thought Presentation in Corpus of English Writing. London: Routledge.

Silverstein, M. (1993). Metapragmatic Discourse and Metapragmatic Function. In J. Lucy (Ed.), Reflexive language (pp. 33-58). Cambridge: Cambridge University Press. https://doi.org/10.1017/CBO9780511621031.004

Sunderland, J., \& Litosseliti, L. (2002). Gender Identity and Discourse Analysis: Teoretical and Empirical Considerations. In L. Litosseliti \& J. Sunderland (Eds.), Gender Identity and Discourse Analysis (pp. 1-39). Amsterdam: John Benjamins Publishing Company. https://doi.org/10.1075/dapsac.2.01sun

Tannen, D. (1986). Introducing Constructed Dialogue in Greek and American Conversational and Literary Narrative. In F. Coulmas (Ed.), Direct and Indirect Speech (pp. 311-332). Berlin: de Gruyter. https://doi.org/10.1515/9783110871968.311

Thornborrow, J., \& Wareing, S. (1998). Patterns in Language: An Introduction to Language and Literary Style. London: Routledge.

Toolan, M. (2009). Speech and Thought: Representation of. In J. L. Mey (Ed.), Concise Encyclopedia of Pragmatics (2nd ed., p. 102). Amsterdam: Elsevier Ltd.

\section{Copyrights}

Copyright for this article is retained by the author(s), with first publication rights granted to the journal.

This is an open-access article distributed under the terms and conditions of the Creative Commons Attribution license (http://creativecommons.org/licenses/by/4.0/). 